\title{
Royalty Fees Transferring Profits
}

The wholly owned foreign enterprise in China is funded by a reputable multinational company with a registered capital of USD 20 million, as in Fig. 33.1. From its establishment in 1995 in Beijing, the company suffered losses or very low margins.

The tax authority conducted a transfer pricing audit in the company, discovering that the accumulated significant losses of the company were due to the high distribution and administrative expenses incurred. The sales revenue was not able to cover these costs. A large proportion of the expenses was the royalty fees paid to the overseas-related company. The fees for research and development services and technical supports provided by the Chinese subsidiary to the parent company and subsequently compensated by the latter were very low.

The tax authority considered that the company had shifted profits outside China via transfer pricing. The Chinese company had undertaken significant manufacturing functions and borne market risks, but the operating performance was not consistent with its functional profile. After auditing, an additional RMB 1 billion of corporate income tax, business tax, and interests were charged to the company.

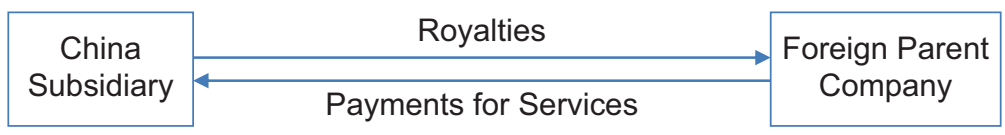

Fig. 33.1 Excessive royalties and low payments for services

(C) The Author(s) 2019

J. Li, A. Paisey, Transfer Pricing in China, https://doi.org/10.1007/978-981-13-7689-4_33 